\title{
Dual-Purpose Solvay-Dow (Magnesium) Conceptual Process
}

\author{
Hussein Abdel-Aal'1, Maha Abdelkreem², Khaled Zohdy² \\ ${ }^{1}$ Professor Emeritus of Chemical Engineering/Petroleum Refining (Retired), NRC, Cairo, Egypt \\ ${ }^{2}$ Department of Chemical Engineering, Higher Technological Institute, Tenth of Ramadan City, Egypt \\ Email: habdelaal@link.net
}

How to cite this paper: Abdel-Aal, H., Abdelkreem, M. and Zohdy, K. (2016) DualPurpose Solvay-Dow (Magnesium) Conceptual Process. Open Access Library Journal, 3: e2998.

http://dx.doi.org/10.4236/oalib.1102998

Received: October 8, 2016

Accepted: November 10, 2016

Published: November 14, 2016

Copyright $\odot 2016$ by authors and Open Access Library Inc.

This work is licensed under the Creative Commons Attribution International License (CC BY 4.0).

http://creativecommons.org/licenses/by/4.0/

\section{c) (i) Open Access}

\begin{abstract}
The proposed process basically combines two decades old processes (Solvay and Dow Magnesium) for the manufacture of soda ash and magnesium, respectively into a single process that also produces "partially-desalinated" water. It does so by subjecting salt brines first, to ammonia causing two simultaneous actions: 1) the absorption of ammonia forming what is called "ammoniated brine", and 2) the precipitation of magnesium ions, found in the brine, as magnesium hydroxide, $\mathrm{Mg}(\mathrm{OH})_{2}$, which is filtered and separated. Next, carbon dioxide is introduced through the bulk of ammoniated brine, brine saturated with ammonia, causing the chemical conversion of both $\mathrm{Na}^{+}$and $\mathrm{Cl}^{-}$into $\mathrm{NaHCO}_{3}$ and $\mathrm{NH}_{4} \mathrm{Cl}$, respectively. Soda ash $\left(\mathrm{Na}_{2} \mathrm{CO}_{3}\right)$ and ammonium chloride $\left(\mathrm{NH}_{4} \mathrm{Cl}\right)$ come as products, along with partially desalinated water. This process is identified as "brine desalting", because of the drastic reduction of the salt content in brine. This part was experimentally tested before by the author and coworkers. Magnesium chloride $\left(\mathrm{MgCl}_{2}\right)$ is obtained, next, by reacting ammonium chloride $\left(\mathrm{NH}_{4} \mathrm{Cl}\right)$ with $\mathrm{Mg}(\mathrm{OH})_{2}$. In this double reaction, ammonia will be regenerated and recycled back to the process: $2 \mathrm{NH}_{4} \mathrm{Cl}+\mathrm{Mg}(\mathrm{OH})_{2} \rightarrow \mathrm{Mg}(\mathrm{Cl})_{2}+2 \mathrm{NH}_{3}$ $+2 \mathrm{H}_{2} \mathrm{O}$. Magnesium chloride is the raw material for making magnesium metal. This makes an additional economic value to the proposed process. The present contribution offers this conceptual scheme as an amalgamation of both Solvay/Dow (Magnesium) processes.
\end{abstract}

\section{Subject Areas}

Green Chemistry

\section{Keywords}

Magnesium Chloride, Soda Ash, Magnesium Metal, Ammonium Chlorid 


\section{Introduction}

A separation process was proposed by Abdel-Aal et al. [1] [2] [3] which utilizes a series of chemical reaction sequences in order to separate $\mathrm{NaCl}$ from highly-saline water resources (sodium chloride-rich brines). The process involves bubbling of $\mathrm{CO}_{2}$ gas into ammoniated brines, thus converting $\mathrm{Na}^{+}$and $\mathrm{Cl}^{-}$into $\mathrm{NaHCO}_{3}$ and $\mathrm{NH}_{4} \mathrm{Cl}$, respectively. Bubble columns were used as chemical reactors. Detailed experimental findings are reported by Ibrahim [4]. More than $80 \% \mathrm{NaCl}$ conversion was achieved for saturated brines, leading to the production of partially desalinated water along with valuable chemical products, namely, soda ash and $\mathrm{NH}_{4} \mathrm{Cl}$.

When it comes to the Solvay process [5] [6] [7] [8] [9], it could be stated that while the soda ash is the main product in this process, it is a by-product in the proposed process. The main product is partially-desalted water that contains ammonium chloride, which may be called "fertile" water, to be used for agriculture purposes.

\section{Proposed Process}

Our proposed process follows the idiom of "killing two birds with one stone". Sea oceans are a virtually inexhaustible source of magnesium [10] [11] [12] [13]. About one pound of magnesium is recovered from each hundred gallon of sea water.

The main two steps involved in the proposed process are:

$1^{\text {st: }}$ : Adding ammonia to our system will trigger the precipitation of magnesium, in the brine, as magnesium hydroxide $\mathrm{Mg}(\mathrm{OH})_{2}$ which is separated first as an intermediate product. Simulateously, brine will get sturatred with ammonia forming what is called "ammoniated brine".

$2^{\text {nd }}$ : Bubbling carbon dioxide gas into the ammoniated brine, will initiate a set of chemical reactions described as follows:

\section{Main Reactions}

- Primary reactions: Takes place between $\mathrm{CO}_{2}$ and $\mathrm{NH}_{3}$ :

(a) $\mathrm{CO}_{2}+\mathrm{NH}_{3} \rightarrow \mathrm{NH}_{2} \mathrm{COOH}$ [carbamic acid]

(b) $\mathrm{NH}_{3}+\mathrm{NH}_{2} \mathrm{COOH} \rightarrow \mathrm{NH}_{4}^{+}+\mathrm{NH}_{2} \mathrm{COO}^{-}$[carbamate]

The net reaction is: $\mathrm{CO}_{2}+2 \mathrm{NH}_{3} \rightarrow \mathrm{NH}_{2} \mathrm{COO}^{-}+\mathrm{NH}_{4}^{+}$.

- Secondary reaction s: In the bulk of the solution, the carbamate hydrolyses comparatively slowly to bicarbonate:

$$
\mathrm{NH}_{2} \mathrm{COO}^{-}+\mathrm{H}_{2} \mathrm{O} \rightarrow \mathrm{NH}_{3}+\mathrm{HOCOO}^{-} .
$$

\section{- $\underline{\text { Product formation reactions }}$}

\subsection{Soda Ash}

In the presence of $\mathrm{NaCl}$, the following instantaneous reaction takes place:

$$
\mathrm{NH}_{4}+\mathrm{HCO}_{3}^{-}+\mathrm{NaCl} \rightarrow \mathrm{NaHCO}_{3}+\mathrm{NH}_{4} \mathrm{Cl} .
$$

This leads to the precipitation of sodium bicarbonate leaving ammonium chloride in 
a partially desalinated water (pdw). Sodium bicarbonate $\left(\mathrm{NaHCO}_{3}\right)$ precipitates from the reaction is converted to the final product, sodium carbonate $\mathrm{Na}_{2} \mathrm{CO}_{3}$ by calcination $\left(160^{\circ} \mathrm{C}-230^{\circ} \mathrm{C}\right)$, producing water and carbon dioxide as byproducts:

$$
2 \mathrm{NaHCO}_{3} \rightarrow \mathrm{Na}_{2} \mathrm{CO}_{3}+\mathrm{H}_{2} \mathrm{O}+\mathrm{CO}_{2} \text {. }
$$

\subsection{Magnesium Chloride}

Part of the partially desalinated water contining ammonium chloride is added separately to magnesium hydroxide forming magnesium chloride along with the regeneration of ammonia gas, to be recycled:

$$
\mathrm{Mg}(\mathrm{OH})_{2}+2 \mathrm{NH}_{4} \mathrm{Cl} \rightarrow \mathrm{MgCl}_{2}+2 \mathrm{NH}_{3}+2 \mathrm{H}_{2} \mathrm{O} .
$$

The modified process, which could be named Modified Solvay Process (MSP) is schematically illustrated in Figure 1.

\section{Final Thoughts on the Duel-Purpose (Solvay-Dow) Process}

A bird's eye view on the MSP compared to current one (shown in Figure 2) indicates some interesting observations:

- For the current Solvay process, $\mathrm{CO}_{2}$ and $\mathrm{Ca}\left(\mathrm{OH}_{2}\right)$ are produced by burning lime stone using metallurgical coke:

$$
\mathrm{CaCO}_{3} \rightarrow \mathrm{CaO}+\mathrm{CO}_{2} .
$$

Next, Quick lime, $\mathrm{CaO}$, is slacked by water: $\mathrm{CaO}+\mathrm{H}_{2} \mathrm{O} \rightarrow \mathrm{Ca}(\mathrm{OH})_{2}$.

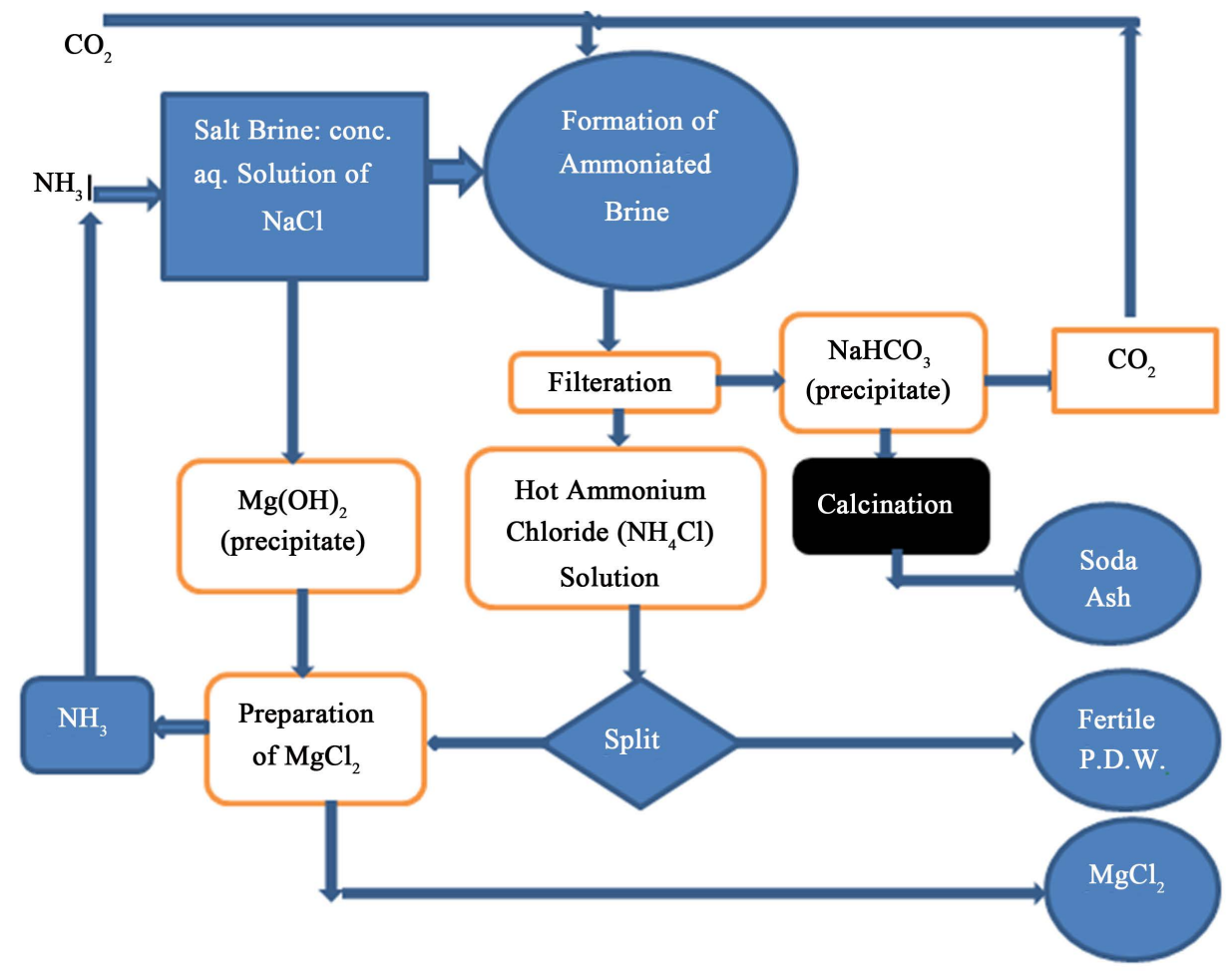

Figure 1. Process flow diagram for the Modified Solvay Process (MSP). 


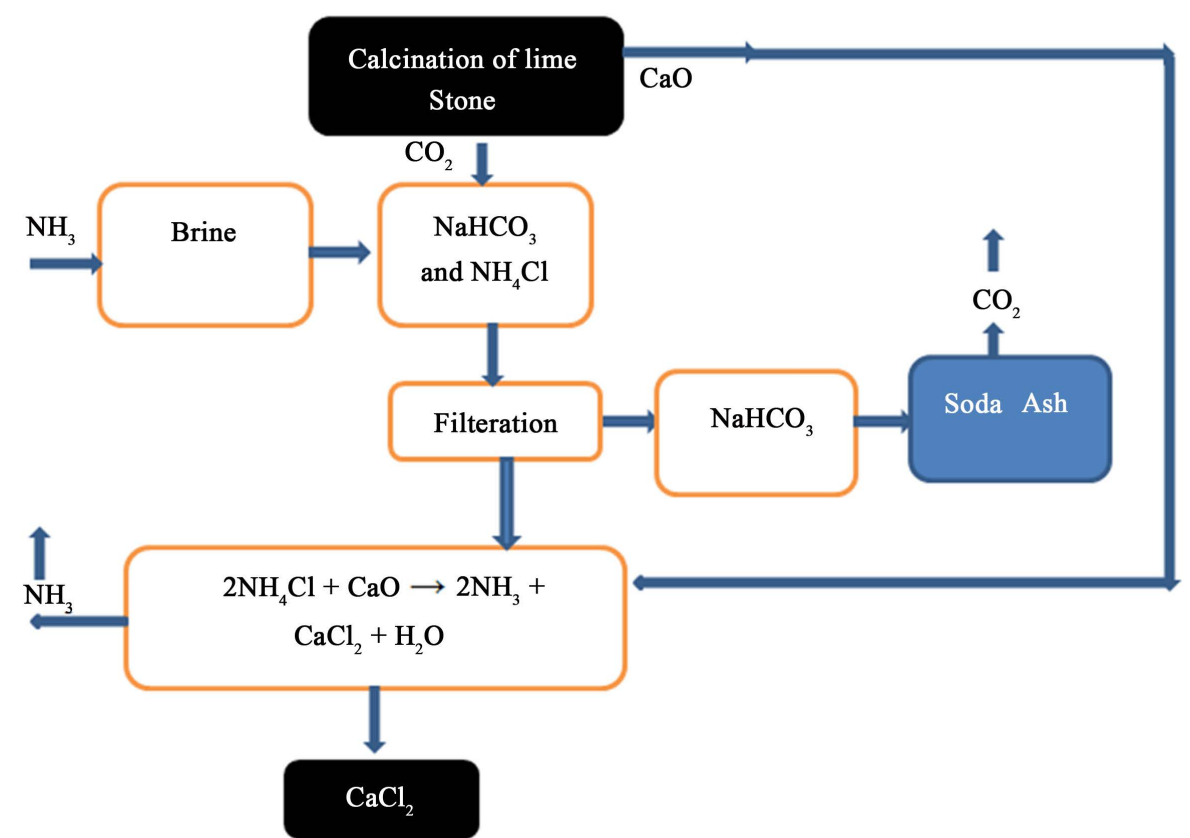

Figure 2. Conventional solvay process.

- In the proposed process, the source of $\mathrm{CO}_{2}$ could be the combustion of fossil fuels in power generation and water desalination plants.

- In the Solvy process, $\mathrm{CaCl}_{2}$ is produced as a waste; and arrangements are done for its disposal.

- The extraction of magnesium as magnesium chloride from sea water by the Dow process implies the precipitation of magnesium as magnesium hydroxide first by slurrying with calcined dolomite and then converting it to magnesium chloride by reacting it next, with hydrochloric acid.

\section{Conclusions}

The proposed process comprises two simultaneous operations: brine desalting and magnesium recovery. It offers a scheme that provides three products, soda ash, magnesium chloride and partially desalted water, as compared to one product by the Solvay process. Regeneration of ammonia is accomplished in the absence of $\mathrm{CaO}$ used in the Solvay process as indicated before.

The option of producing fertile water, (partially desalted water) containing $\mathrm{NH}_{4} \mathrm{Cl}$ could be a feasible choice to be sold as a fertilizer for rice crops [14].

The proposed process offers a novel scheme, different from the well-known Dow process, for the extraction of magnesium chloride from sea water by eliminating the use of hydrochloric acid [15]. The separation of magnesium chloride as a byproduct adds an economic value to the proposed process.

\section{References}

[1] Abdel-Aal, H.K., Ibrahim, A.A., Shalabi, M.A. and Al-Harbi, D.K. (1996) Chemical Separa- 
tion Process for Highly Saline Water. Industrial Engineering Chemistry Research, 35, 799. https:/doi.org/10.1021/ie9405706

[2] Abdel-Aal, H.K., Ibrahim, A.A., Shalabi, M.A. and Al-Harbi, D.K. (1997) Dual-Purpose Chemical Desalination Process. Desalination, 113, 19-25. https:/doi.org/10.1016/S0011-9164(97)00111-2

[3] Abdel-Aal, H. and Zohdy, K.M. (2013) Chemical Desalting of Saline Water Using Ammonia and Carbon Dioxide, Section D-Short Communication. European Chemical Bulletin, 2, 352-354.

[4] Ibrahim, A.A. (1993) Chemical Separation Process for Highly Saline Water Resources. Ph.D. Dissertation, KFUPM, Dhahran.

[5] Kostick, D. (2006) Soda Ash. Chapter in 2005 Minerals Yearbook, United States Geological Survey.

[6] Kiefer, D.M. (2008) It Was All about Alkali. Today’s Chemist at Work, 11, 45-60.

[7] Reilly, D. (1951) Salts, Acids \& Alkalis in the 19th Century. A Comparison between Advances in France, England \& Germany. Isis, 42, 287-296. https:/doi.org/10.1086/349348

[8] Speight, J. (2001) Chemical Process and Design Handbook. McGraw Hill.

[9] Cohn, E.V.J., Rostanski, A., Tokarska-Guzik, B., Trueman, I.C. and Wozniak, G. (2001) The Flora and Vegetation of an Old Solvay Process Tip in Jaworzno (Upper Silesia, Poland). Acta Societatis Botanicorum Poloniae, 70, 47-60. https:/doi.org/10.5586/asbp.2001.008

[10] Australia’s Identified Mineral Resources (2002) Canberra, Geoscience Australia. http://www.ga.gov.au/pdf/RR0112.pdf

[11] (2010) www.intlmag.org International Magnesium Association. Wacounda, IL USA.

[12] Aghion, E. and Bartos, S.C. (2008) Comparative Review of Primary Magnesium Production Technologies as Related to Global Climate Change. 65th Annual World Magnesium Conference, 97-104.

[13] Cherubini, F., Raugei, M. and Ulgiati, S. (2008) LCA of Magnesium Production. Technological Overview and Worldwide Estimation of Environmental Burdens.

[14] (1998) Fertilizer Manual by United Nations Industrial Development Organization, International Fertilizer Development Center, Kluwer Acadamic Publishers.

[15] www.innovateus.net/science/can-magnesium-be-extracted-seawater

\section{Submit or recommend next manuscript to OALib Journal and we will provide best} service for you:

- Publication frequency: Monthly

- 9 subject areas of science, technology and medicine

- Fair and rigorous peer-review system

- Fast publication process

- Article promotion in various social networking sites (LinkedIn, Facebook, Twitter, etc.)

- Maximum dissemination of your research work

Submit Your Paper Online: Click Here to Submit

Or Contact service@oalib.com 